\title{
Firm Debt Covenants and the Macroeconomy: The Interest Coverage Channel
}

\author{
Daniel L. Greenwald* \\ Preliminary Draft
}

February 13, 2019

\begin{abstract}
Interest Coverage covenants, which set a maximum ratio of interest payments to earnings, are among the most popular provisions in firm debt contracts. For affected firms, the amount of additional debt that can be issued without violating these covenants is highly sensitive to interest rates. Combining a theoretical model with firm-level data, I find that Interest Coverage limits generate strong amplification from interest rates into firm borrowing and investment. Importantly, most firms that have Interest Coverage covenants also face a maximum on the ratio of the stock of debt to earnings. Simultaneously imposing these limits implies a novel source of state-dependence: when interest rates are high, interest coverage limits are tighter, amplifying the influence of interest rate changes and monetary policy. Conversely, in low-rate environments, debt-to-earnings covenants dominate and transmission is weakened.
\end{abstract}

\section{Introduction}

Corporate investment has long been considered a principal driver of the business cycle, and one of the central pathways through which monetary policy affects real activity. ${ }^{1}$ Of particular interest to the literature has been the vast market for corporate debt - measured at over $\$ 6 \mathrm{~T}$ in $2018^{2}$. Specifically, a wide body of work has studied how firm borrowing capacity is influenced by monetary

*Sloan School of Management, MIT, 100 Main Street, Cambridge, MA, 02142, dlg@mit.edu. Mary Gong provided excellent research assistance on this project.

${ }^{1}$ See e.g., Bernanke and Gertler (1995).

${ }^{2}$ Source: Federal Reserve Board of Governors. Series is Nonfinancial Corporate Business, Debt Securities (Liability), FRED code NCBDBIQ027S. 
policy, a mechanism known as the "financial accelerator" after the seminal paper by Bernanke, Gertler, and Gilchrist (1999).

The traditional approach in this literature has been to model a firm's debt capacity based on its market leverage, which is the solution to a particular limited commitment problem. ${ }^{3}$ In practice, firms face a number of explicit constraints on how much they can borrow, many of which are quite different from caps on market leverage. In particular, I focus in this paper on the implications of debt covenants: agreements in debt agreements that constrain future lending. These covenants are extremely common, and often impose mechanical limits on firm financial ratios. However, little is known about how these real-world constraints influence macroeconomic dynamics. As the results will show, the specific structure of these covenants can have important effects on how interest rates transmit into firm borrowing and investment.

Central to my results are Interest Coverage (IC) covenants that limit the ratio of a firm's interest payments to a measure of its earnings, usually EBITDA. ${ }^{4}$ Unlike other covenants that are commonly applied to firms, IC limits on borrowing are extremely sensitive to interest rates, so that a 100bp fall in rates relaxes the debt limit allowed by an IC covenant for a typical firm by roughly $10 \%$. Analysis of firm debt covenants in DealScan syndicated loan data indicates that these covenants are highly prevalent, and are held by $85 \%$ of firms with covenants in this sample. Moreover, lenders have imposed maximum ratios on IC covenants that have been stable over time, even as interest rates have undergone major variation, implying economically important fluctuations in the corresponding debt limits.

To investigate the quantitative impact of these covenants, I develop a simple theoretical model in which firms prefer to finance themselves with debt, due to its tax-preferred status, and face payout frictions that encourage them to smooth dividends over time. The first main finding is that the presence of IC covenants dramatically alter interest rate transmission. Firms in the model with IC covenants take advantage of increased debt capacity by investing, increasing their capital stock by $6.6 \%$ over 8 quarters in response to a $100 \mathrm{bp}$ fall in rates. This investment response far outpaces firms facing the most common alternative covenants - limits on the stock of debt to earnings (Debt-to-Earnings or "DE" covenants) and on firm debt to assets (Leverage covenants) - which display $8 \mathrm{Q}$ capital growth of $1.6 \%$ and $1.9 \%$, respectively. Because IC covenants are also relaxed by increases in earnings, a feedback loop emerges between debt and investment for firms with IC covenants, such that higher earnings account for nearly one-third of the $11.9 \% 8 \mathrm{Q}$ growth in corporate debt.

This analysis is complicated by the fact that the vast majority of firms do not face a single debt covenant, but face multiple limits at once. As a result, the amplification just described is only relevant to the extent that firms perceive their IC covenants as their relevant debt limits. This

\footnotetext{
${ }^{3}$ Specifically, the costly state verification model of Townsend (1979).

${ }^{4}$ EBITDA stands for Earnings Before Interest, Taxes, Depreciation, and Amortization.
} 
tension leads to the second main theoretical insight, which is that simultaneously imposing IC covenants alongside the most common alternative covenants leads to state dependent transmission. Specifically, a change in interest rates has a stronger effect on debt and investment when interest rates initially high relative to when they are low. The key idea is that IC covenants, which are much more sensitive to interest rates, become tighter and more likely to bind when interest rates are high. Imposing the observed dispersion in covenant limits in the model shows that the $8 \mathrm{Q}$ growth of capital among firms constrained by both IC and non-IC covenants is more than twice as large in a high rate environment with rates $300 \mathrm{bp}$ above the baseline ( $4.6 \%$ growth) as in a low rate environment with rates $300 \mathrm{bp}$ below baseline (1.9\% growth).

To support these findings, I merge syndicated loan data from DealScan with firm-level data from Compustat, to study the empirical response to changes in interest rates. I compare the differential responses across firms with IC covenants, non-IC covenants, and no observed covenants. While not always precise, the results indicate that amplification of borrowing and investment through IC covenants is statistically and economically significant in the data. Firms with IC covenants increase their Property, Plant, and Equipment by an average of $8.4 \%$ more than firms with Debt/Earnings covenants, despite being otherwise highly similar on observables. Turning to the finding of state dependence, the results indicate that the investment response of firms with both IC and non-IC covenants is significantly higher when current short rates are high vs. low, but that the investment response of firms with only IC covenants is equally strong in either regime. Overall, these empirical findings are highly consistent with the core theoretical results of the model.

Literature Review. This paper connects to several strands of the literature. Most relevant are recent papers by Lian and Ma (2017) and Dreschel (2018), who emphasize that firm debt covenants are often written proportional to firm earnings or EBITDA, instead of the traditional market leverage limit. This paper complements these works by focusing on two additional properties of debt covenants. First, I focus on Interest Coverage covenants, which crucially depend not only on firm earnings, but also on the firm's interest rate. This distinction is central for the results on interest rate transmission, which show that the response firms with Interest Coverage covenants is dramatically different from firms with Debt/Earnings covenants, despite the fact that both depend on earnings in the same way. Second, I allow for firms to be limited by multiple covenants at the same time. This feature is essential for the finding of state dependence.

[Remaining literature review to be completed.] 


\section{Background: Debt Covenants}

Definition of Debt Covenants. Debt covenants are provisions in credit agreements that define conditions with which the firm is obligated to satisfy, as well as the consequences if the firm violates the conditions. While credit agreements typically include many covenants on a variety of topics, the covenants relative to this paper are "financial covenants," which specify that the firm must maintain financial statistics within certain bounds (e.g., a maximum on the ratio of interest payments to EBITDA). Importantly, these statistics are usually measured at the firm level, implying that covenants related to debt or interest payments restrict a firm's total borrowing from all sources, not only the borrowing on that particular credit facility.

The consequences for violation can vary, and often depend on the type of credit instrument. For corporate loans, considered in the empirical analysis of this paper, a violation typically gives the lender the right, but not the obligation, to demand immediate repayment of the loan. ${ }^{5}$ In practice, lenders typically do not demand full repayment upon violation, but instead renegotiate the terms of the loan, often extracting some concession in the form of a higher interest rate or up-front fee in exchange for waiving the covenant violation.

While covenants to not provide a hard cap on borrowing, and in fact are violated with some frequency, violation is costly for firms, typically leading to adverse outcomes, as found in Roberts and Sufi (2009). Correspondingly, Lian and Ma (2017) find evidence of bunching before financial ratios that would induce violation. These findings support the interpretation of covenants as setting limits that, while not unbreakable, are costly enough that firms seek to avoid crossing them.

Covenant Types. Most financial covenants that limit debt accumulation fall in one of three categories.

First, Interest Coverage (IC) covenants that set a maximum on the ratio of interest payments to a measure of firm earnings, usually EBITDA (Earnings Before Interest, Taxes, Depreciation, and Amortization). These limits are also frequently expressed as an equivalent minimum on the ratio of earnings to interest payments. This type of covenant can also go by alternative names, such as Fixed Charge Coverage, Debt Service Coverage, and Cash Interest Coverage, which can vary slightly in how the ratio is computed.

Second, Debt/Earnings (DE) covenants limit the stock of firm debt to be no less than some multiple of earnings (typically EBITDA). Crucially, unlike Interest Coverage covenants, Debt/Earnings covenants are not directly affected by the interest rate.

\footnotetext{
${ }^{5}$ In contrast, corporate bonds typically impose constraints on firm behavior, for example the payment of dividends, while a firm is in violation. This is due to the dispersed ownership of bonds, making renegotiation difficult in case of violation.
} 
Third and last, Leverage covenants limit firm debt to be no more than some multiple of firm assets. Variations on this theme include limits on the Current Ratio, Quick Ratio, Debt to Equity Ratio, Equity to Asset Ratio, and Debt to Tangible Net Worth Ratio. Unlike in many macroeconomic implications, these covenants are typically measured using book values, not market values, preventing feedback through the market price of capital or the market value of equity.

Simple Example of Interest Rate Transmission. Most important for this analysis, Interest Coverage covenants imply debt limits that are highly sensitive to interest rates, with firm borrowing capacity moving by $10 \%$ or more in response to a one percent change in interest rates. To see this, consider a firm that is currently paying a $10 \%$ interest rate, which might be typical in an environment with a $4 \%$ risk-free rate, and a $600 \mathrm{bp}$ spread. Let's further suppose that that the firm's covenants allow a maximum ratio of interest payments to EBITDA of 40\%, and that the firm's EBITDA is $\$ 10 \mathrm{M}$. The firm's IC covenant then implies a maximum of $\$ 4 \mathrm{M}$ in annual interest payments, which at a $10 \%$ interest rate corresponds to $\$ 40 \mathrm{M}$ of debt. If the interest rate now falls from $10 \%$ to $9 \%$, the firm's maximum interest payment remains unchanged at $\$ 4 \mathrm{M}$ per year. However, at the reduced interest rate, this same interest payment is associated with a larger debt balance of $\$ 44.4 \mathrm{M}$, an increase of over $10 \%$.

Covenant Prevalance by Type. To give a sense of the prevalence of different covenants, Figure 1 shows the equally-weighted share of firms with different covenant configurations. Since DealScan covers only a fraction of firms in the market, the unconditional shares confound the relative popularity of each covenant with the overall coverage of the DealScan data. To avoid this, I plot prevalence of each covenant or covenant pair firms that have at least one DealScan covenant. Thus, Figure 1 shows time variation in the relative popularity of various covenants, rather than the absolute probability of using any covenants at all.

Panel 1a shows the relative prevalence of each type of covenant. Since firms can have more than one covenant, the shares do not add to unity. As can be seen, covenants in the Interest Coverage family are the most popular, trailed closely by Debt/Earnings covenants. Although Leverage covenants were more popular at the start of the sample, their appearance in this data has declined over time to the point that they are much less common than the other two types toward the end of the sample. Overall, this pattern is consistent with the findings of Lian and Ma (2017), who document the prevalence of "earnings-based covenants" such as Interest Coverage and Debt/Earnings.

Next, Panel $1 \mathrm{~b}$ documents the prevalence of covenant pairs. As can be seen, multiple covenants is the norm, not the exception, in corporate lending. In fact, the majority of firms with any covenant in this data have a specific covenant pair, possessing both Debt/Earnings and Interest Coverage covenants. The prevalence of this combination is stable over time in the data, and does not vary 


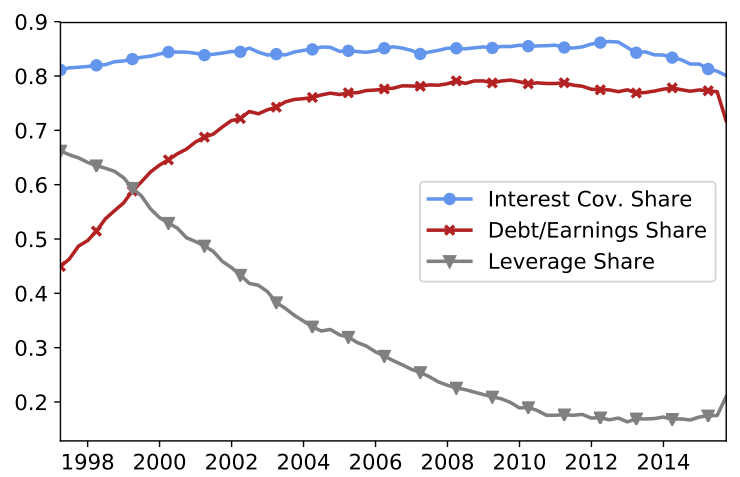

(a) Share with Each Covenant

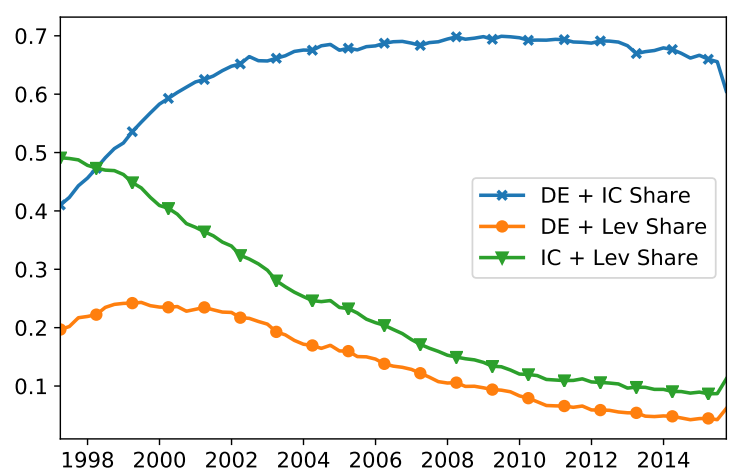

(b) Share with Covenant Pair

Figure 1: Covenant Ratios Over Time

Note: Data source is DealScan. Each series is the equally weighted share of firms with that particular covenant configuration among firms that DealScan reports has at least one covenant.

with economic conditions. The popularity of this pair will motivate further analysis in Section 4. The other two covenant pairs have appeared less frequently over time, simply due to the fact that they both include Leverage covenants, which have become less popular over the sample.

Firm Characteristics by Covenant. The assignment of covenants to firms is not random, making it important to analyze the difference between firms with and without each covenant type. In this section, I present summary statistics suggesting that, while firms with and without covenants appear quite different, firms with different covenants appear similar to each other, especiall Interest Coverage and Debt/Earnings covenants. This finding motivates the empirical cross-covenant comparisons in Section 5.

Table 1 provides the typical (median) value for a number of firm variables for firms with different covenant configurations. Since, as shown in Figure 1, some covenants appear more or less frequently over time measuring summary statistics in dollars could be misleading when weighted across different time periods. To address this, I include both medians of variables in levels, as well as medians of variables that have first been scaled by its overall median for that period across all firms. These values indicate how many times larger is the value of the typical firm in that group relative to the typical firm overall. Variables that are already in ratios do not require this adjustment and are reported in the bottom panel in levels.

As can be seen, substantial differences exist between firms with and without covenants, and across covenant types. First, comparing firms with and without covenants, we observe that firms with covenants are much larger in scale than firms without covenants, both in terms of sales, as well as in the size of their balance sheets. Firms with covenants are also much more highly levered than firms with no covenants. These facts are consistent with larger firms selecting into 
Table 1: Firm Medians by Covenant Type

\begin{tabular}{|c|c|c|c|c|c|c|c|}
\hline & None & IC & $\mathrm{DE}$ & Lev & $\mathrm{IC}+\mathrm{DE}$ & $\mathrm{IC}+\mathrm{Lev}$ & $\mathrm{DE}+\mathrm{Lev}$ \\
\hline & \multicolumn{7}{|c|}{ Levels (Million USD) } \\
\hline Sales & 8.56 & 118.36 & 125.05 & 70.08 & 129.36 & 82.89 & 86.52 \\
\hline EBITDA & 0.39 & 13.99 & 15.42 & 7.22 & 16.30 & 8.43 & 9.00 \\
\hline Assets & 57.33 & 449.83 & 490.86 & 257.44 & 516.04 & 300.89 & 316.89 \\
\hline PPE & 5.24 & 96.72 & 103.79 & 56.06 & 109.22 & 69.38 & 70.90 \\
\hline Debt & 2.88 & 138.26 & 160.90 & 52.78 & 173.76 & 69.74 & 76.50 \\
\hline ST Debt & 0.46 & 5.48 & 5.76 & 3.74 & 5.92 & 4.33 & 4.37 \\
\hline LT Debt & 0.77 & 115.31 & 137.80 & 34.71 & 150.00 & 50.06 & 58.09 \\
\hline \multirow[t]{2}{*}{ Cash } & 7.95 & 14.80 & 16.49 & 12.31 & 16.13 & 10.53 & 11.00 \\
\hline & \multicolumn{7}{|c|}{ Scaled Levels (Multiple of Quarter Median) } \\
\hline Sales & 0.43 & 5.64 & 5.83 & 3.69 & 6.07 & 4.33 & 4.42 \\
\hline EBITDA & 0.22 & 7.89 & 8.68 & 4.19 & 9.20 & 4.91 & 5.23 \\
\hline Assets & 0.48 & 3.68 & 3.93 & 2.23 & 4.12 & 2.60 & 2.68 \\
\hline PPE & 0.42 & 7.58 & 8.00 & 4.58 & 8.42 & 5.59 & 5.62 \\
\hline Debt & 0.30 & 14.24 & 16.80 & 5.31 & 18.05 & 6.87 & 7.67 \\
\hline ST Debt & 0.42 & 5.11 & 5.45 & 3.33 & 5.57 & 3.88 & 3.97 \\
\hline LT Debt & 0.19 & 28.07 & 34.33 & 7.97 & 37.45 & 11.39 & 13.64 \\
\hline \multirow[t]{2}{*}{ Cash } & 0.80 & 1.40 & 1.51 & 1.30 & 1.49 & 1.14 & 1.15 \\
\hline & \multicolumn{7}{|c|}{ Ratios } \\
\hline Debt/EBITDA & 0.00 & 8.44 & 8.97 & 5.49 & 9.47 & 6.56 & 7.16 \\
\hline Debt/Assets & 0.12 & 0.32 & 0.33 & 0.24 & 0.34 & 0.27 & 0.28 \\
\hline Market-to-Book & 1.72 & 1.38 & 1.40 & 1.39 & 1.39 & 1.34 & 1.35 \\
\hline$N$ & 184,275 & 69,824 & 56,782 & 36,962 & 51,028 & 27,506 & 16,360 \\
\hline
\end{tabular}

Note: Data source is DealScan and Compustat. The sample is 1994Q1 - 2007Q4. All entries are sample medians. For "Scaled Levels" (top panel), each value is divided by the quarterly median for that variable across all firms, before the median is taken by covenant type. For "Ratios" the values are not scaled before the median is taken. Covenant categories are as follows: "None" firms have no DealScan covenants, "IC" firms have an Interest Coverage covenant, "DE" firms have a Debt/Earnings covenant, and "Lev" firms have a Leverage covenant. The remaining categories are for multiple covenants, so that e.g., "IC + DE" firms have both an Interest Coverage and Debt/Earnings covenant. Variable definitions and Compustat codes are as follows. Sales (code: SALEQ). EBITDA is Earnings Before Interest, Taxes, Depreciation, and Amortization (code: OIBDPQ). Assets (code: ATQ). PPE is Property, Plant, and Equipment (code: PPENTQ). Debt is the sum of ST (short-term) debt (code: DLCQ) and LT (long-term) debt (code: DLTTQ). Cash (code: CHEQ). Market-to-book is the ratio of market equity to book equity. $N$ is the number of variables with a non-missing value for PPE in the sample.

the syndicated loan market, as well as with the analysis of Lian and Ma (2017), who argue that constraints that depend on firm earnings, like Interest Coverage and Debt/Earnings covenants, are not practical for very small or young firms that do not have consistent earnings, and who 
generally find it more difficult to borrow. This implies that interest rate transmission may be quite different for firms with and without covenants due to their size or business model, and not due to the covenants themselves.

On the other hand, among firms with earnings-based covenants, differences across firms are more muted. The main discrepancy that firms with Leverage covenants tend to be smaller than firms with other covenants, again fitting the idea that earnings-based covenants are a better fit for larger firms. Firms with Interest Coverage and Debt/Earnings covenants appear quite similar, but this is in part because these covenants are very frequently observed together (see Figure 1b), so that these statistics are largely drawn from the same firms. However, Table 3 in the Appendix shows that firms with each of these constraints alone are similar as well. Finally, for the covenant pairs, the combination of Interest Coverage and Debt/Earnings constraints looks unsurprisingly much like the firms with each of the covenants individually, albeit slightly larger, while firms whose pairs include a leverage covenant mostly fall between the IC or DE and Leverage columns.

Covenant Ratios. Next, we can examine how these covenant ratios have evolved over time. Overall, the data, plotted in Figure 2, indicate that the ratio limits used in debt covenants are stable over time, implying that debt limits can be reasonably treated as fixed at business cycle frequencies. Panels $2 \mathrm{a}$ and $2 \mathrm{~b}$ show the maximum Debt/EBITDA ratios and minimum interest coverage (EBITDA to interest payment) ratios on newly originated deals only, weighted both by the sales of the borrowing firm and by the size of the deal. The series are somewhat noisy, since the subset of firms obtaining new deals varies from quarter to quarter, but neither of the series show substantial time variation, with the exception of a slight upward trend in the allowed interest coverage ratio.

A possible concern is be that lenders use these simple covenant ratios to dynamically implement some more complex limit policy, and simply change the ratios limits imposed by the covenants to keep the overall limit unchanged. If this were the case, we should expect to see that the ratio limits imposed on new loans vary with the actual ratios observed in firms. For example, if lenders were using Interest Coverage limits as a proxy for another policy, we should expect that lenders would loosen Interest Coverage requirements as interest rates rise, so that overall debt limits remain unchanged.

To address this concern, panels $2 \mathrm{c}$ and $2 \mathrm{~d}$ plot the covenant ratios on new loans, weighted by deal amount, against measures of the overall Debt/EBITDA and Interest Coverage ratios among corporate nonfinancial firms in the NIPA data. These plots show that the imposed limits do not co-move at all as the underlying variables change, despite substantial variation in the underlying fundamentals. For example, despite the large increase in the ratio of corporate profits to interest payments, due to falling interest rates, minimum interest coverage ratios have not risen nearly enough to keep debt limits constant. 


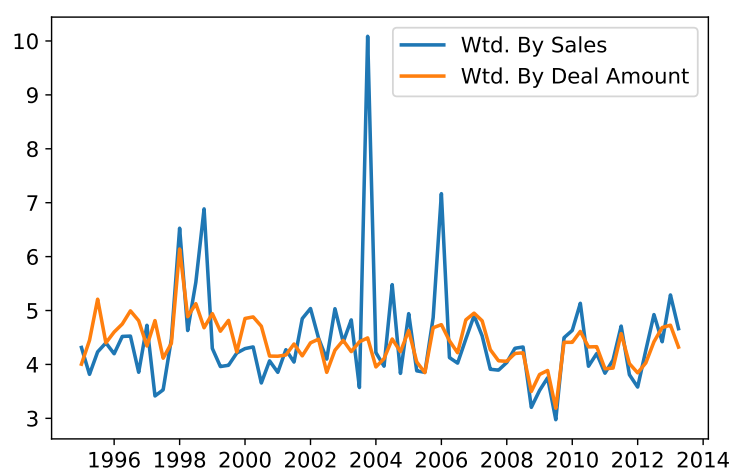

(a) Max Debt/Earnings Ratio

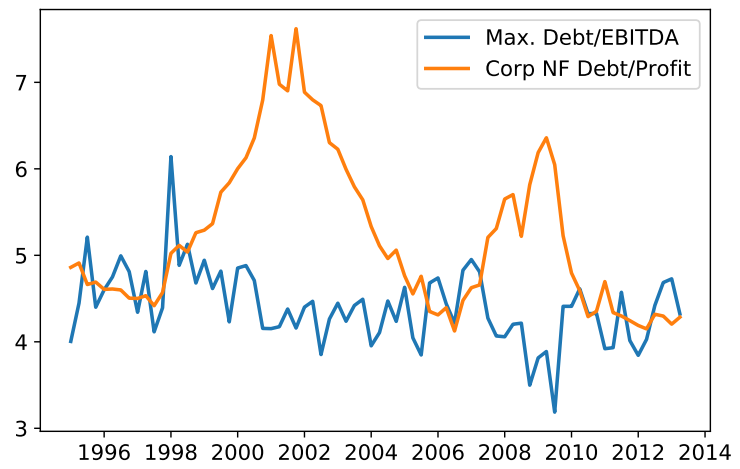

(c) Debt/Earnings: New Covs. vs. Data

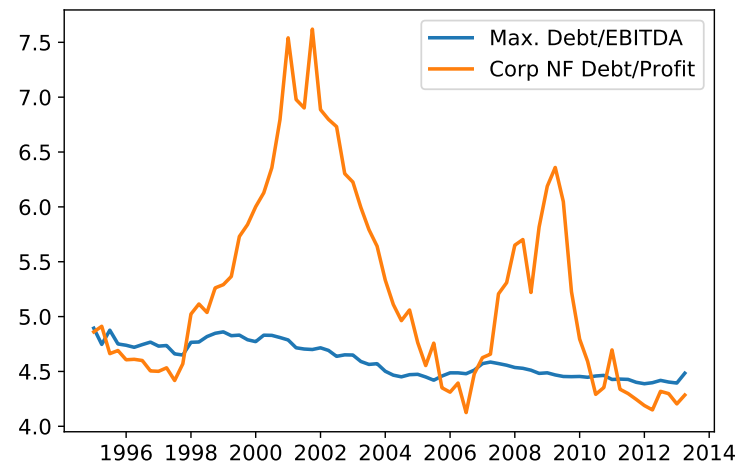

(e) Debt/Earnings: All Covs. vs. Data

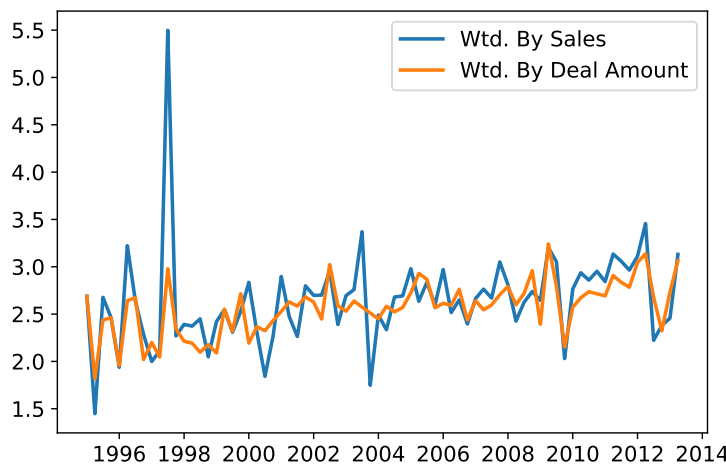

(b) Min Interest Cov. Ratio

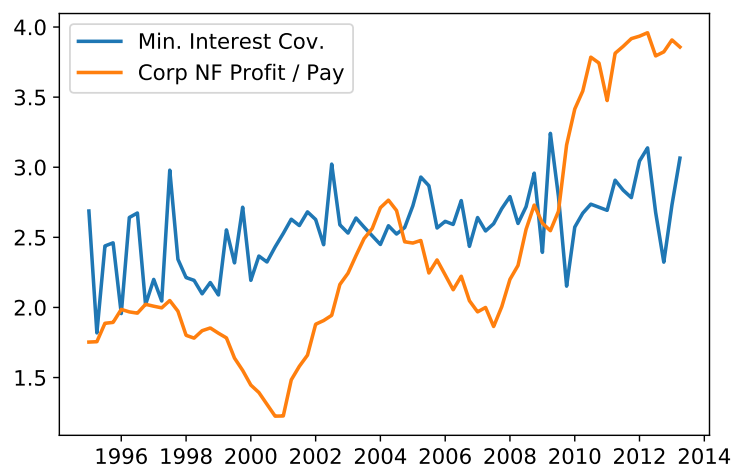

(d) Interest Cov.: New Covs. vs. Data

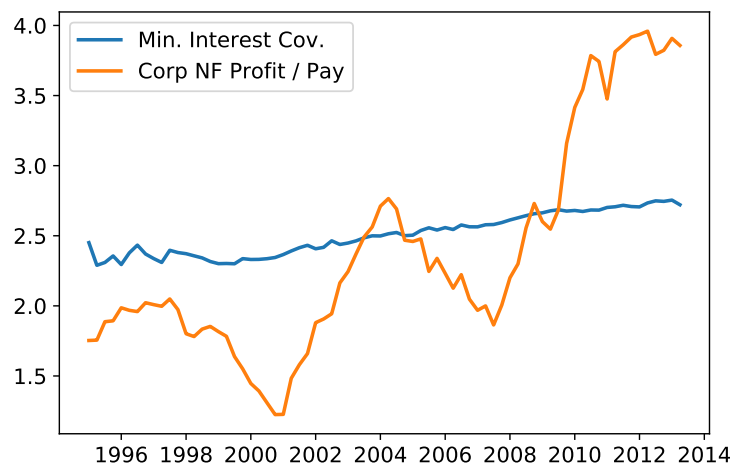

(f) Interest Cov.: All Covs. vs. Data

Figure 2: Covenant Ratios Over Time

Note: Data sources are DealScan, Compustat, and the National Income and Product Accounts.

Finally, while the previous discussion considers the covenant ratios on new loans, covenants on existing debt continue to constrain firms throughout the life of the loan. To show firms' actual constraints, panels $2 \mathrm{e}$ and $2 \mathrm{f}$ compare covenant limits on all active DealScan loans to the same aggregate fundamentals. These plots show that overall covenant limits are extremely smooth, and 
do not vary with economic conditions at business cycle frequencies.

\section{Model}

Demographics. The model is populated a continuum of infinitely-lived households. These households can trade a complete set of contingent contracts with each other (but not with firms) allowing for aggregation to a representative household.

Preferences. Households have time-separable expected utility, defined by

$$
V_{t}=E_{t} \sum_{j=0}^{\infty}\left(\prod_{k=0}^{j-1} \beta_{t+k}\right)\left[u\left(C_{t+j}\right)-v\left(N_{t+j}\right)\right]
$$

where $C$ represents nondurable consumption, $N$ represents labor supply, and this discount factor $\beta_{t}$ follows

$$
\log \beta_{t}=\left(1-\rho_{\beta}\right) \log \bar{\beta}+\rho_{\beta} \log \beta_{t-1}+\varepsilon_{\beta, t}, \quad \varepsilon_{\beta, t} \sim N\left(0, \sigma_{\beta}^{2}\right)
$$

allowing for time variation in real discount rates.

Productive Technology The productive technology in the economy is defined by

$$
F\left(K_{t-1}, N_{t}\right)=Z_{t} K_{t-1}^{\alpha} N_{t}^{1-\alpha}
$$

where productivity $Z_{t}$ follows an autoregressive process in logs

$$
\log Z_{t}=\left(1-\rho_{Z}\right) \log \bar{Z}+\rho_{Z} \log Z_{t-1}+\varepsilon_{Z, t}, \quad \varepsilon_{Z, t} \sim N\left(0, \sigma_{Z}^{2}\right)
$$

Covenant Types. The main modeling innovation of the paper is to consider the three main types of covenants imposed on firm debt. First, a Debt-to-EBITDA or "DE" covenant sets a cap on the ratio of a firm's debt balance to its EBITDA. In the model, this is imposed as a maximum debt balance $\bar{B}_{t}^{D E}$ given by

$$
\bar{B}_{t}^{D E}=\theta^{D E} X_{t}
$$

where $X_{t}$ denotes EBITDA, defined in the model as

$$
X_{t}=Y_{t}-w_{t} N_{t}
$$

i.e., output net of the wage bill (production costs). 
Second, an Interest Coverage or "IC" covenant sets a cap on the ratio of a firm's interest payments to its EBITDA, which is imposed as

$$
\bar{B}_{t}^{I C}=\frac{\theta^{I C} X_{t}}{r_{t}+\omega}
$$

To understand this expression, note that for $\omega=0$ it corresponds to $r_{t} \bar{B}^{I C}=\theta^{I C} X_{t}$. The additional constant $\omega$ is used to obtain a realistic calibration - since debt in the model is risk-free, $r_{t}$ would otherwise be too low relative to the actual rates that firms pay (which in reality contain large spreads) leading to unrealistically loose IC limits.

Third, a Leverage covenant sets a cap on the ratio of a firm's debt balance to its book value. In the model, this is imposed as

$$
\bar{B}_{t}^{L E V}=\theta^{L E V} K_{t-1}
$$

where $I_{t}$ is investment, and $\delta$ is the depreciation rate.

Combining Covenants. Firms can be allowed to face multiple covenants at once. This is more realistically implemented by allowing for heterogeneity in the covenant limits by firm, so that an endogenous and time-varying fraction of find each covenant to be their binding constraint. In this section I describe how to jointly implement Debt/Earnings and Interest Coverage covenants, but the implementation of another combination would be very similar.

Since the production function is constant returns to scale, and both Debt/Earnings and Interest Coverage covenants scale linearly with production, in the absence of additional frictions all production would simply be performed by whichever firm happened to end up with the loosest debt limit. To address this, I impose a simple timing friction that imposes heterogeneity in the binding constraint while keeping the firms' choices symmetric. Specifically, I assume that firms draw a new set of covenant ratios (i.i.d.) and require firms to choose their investment rate before observing the outcome of their draw. ${ }^{6}$

To implement this, I assume that all firms in the economy share the same Debt/Earnings limit $\bar{\theta}^{D E}$. However, each firm draws a firm-specific Interest Coverage limit $\theta_{i, t}^{I C}=e_{i, t} \bar{\theta}^{I C}$, where $\log e_{i, t} \sim N\left(-\sigma_{e}^{2} / 2, \sigma_{e}^{2}\right)$. If we define

$$
\bar{B}_{t}^{D E}=\bar{\theta}^{D E} X_{t}, \quad \bar{B}_{t}^{I C}=\bar{\theta}^{I C} X_{t} /\left(r_{t}+\omega\right)
$$

to be the average values of the these limits, then a firm will have a binding IC constraint if and

\footnotetext{
${ }^{6}$ Other options to deal with this issue would be imposing decreasing returns to scale technology or monopolistic competition, so that firms with lower debt limits would still have reason to produce.
} 
only if $e_{i, t} \leq e_{t}^{*}=\bar{B}_{t}^{D E} / \bar{B}_{t}^{I C}$. The overall debt limit for a given firm is

$$
\bar{B}_{i, t}=\min \left(\bar{B}_{t}^{D E}, e_{i, t} \bar{B}_{t}^{I C}\right)
$$

which is equivalent to the representative firm facing the overall debt limit

$$
\bar{B}_{t}^{D E / I C}=\bar{B}_{t}^{I C} \int^{e_{t}^{*}} e_{i, t} \Gamma_{e}\left(e_{i, t}\right)+\bar{B}_{t}^{D E}\left(1-\Gamma_{e}\left(e_{t}^{*}\right)\right)
$$

Collateralizability in this case is equal to

$$
\frac{\partial \bar{B}_{t}^{D E / I C}}{\partial K_{t-1}}=\frac{\partial \bar{B}_{t}^{I C}}{\partial K_{t-1}} \int^{e_{t}^{*}} e_{i, t} \Gamma_{e}\left(e_{i, t}\right)+\frac{\partial \bar{B}_{t}^{D E}}{\partial K_{t-1}}\left(1-\Gamma_{e}\left(e_{t}^{*}\right)\right)
$$

while the fraction of borrowers with binding Interest Coverage constraints is equal to $\Gamma_{e}\left(e_{t}^{*}\right)$.

Debt Limit Smoothing. To accommodate the fact that covenants are often written at the annual rather than the quarterly frequency, I assume that the overall debt limit is a moving average of the current covenant limits $\bar{B}$ defined above. Specifically, I set firms' overall debt caps to be

$$
B_{t}^{*}=\left(1-\rho_{B}\right) \bar{B}_{t}+\rho_{B} \pi_{t}^{-1} B_{t-1}^{*} .
$$

This smoothing is a parsimonious approximation of the fact that covenants are often written on annual rather than quarterly ratios, so that total debt limits are mixed over current and past conditions. To stay consistent with the notion of these limits as covenants, I require that they be satisfied not at time $t$, but in expectation at time $t+1$, so that the firm's time $t$ debt limits is defined by

$$
B_{t} \leq E_{t}\left[B_{t+1}^{*}\right]
$$

Firms. Firms own the economy's productive capital and produce using the production function $F\left(K_{t-1}, N_{t}\right)$. Firms are owned by the household, who receive dividends $D_{t}$. Firms are also able to borrow in the form of debt, denoted $B_{t}$, whose interest payments are tax deductible, generating a tax shield, as well as a preference for debt finance. Following Jermann and Quadrini (2012), I introduce dividend adjustment costs so that expending $D_{t}$ on dividends results in $\Psi\left(D_{t}\right)$ units of dividends being paid out. Firm investment in capital is also subject to adjustment costs, so that expending $I_{t}$ units of resources results in $\Phi\left(i_{t}\right) K_{t-1}$ new units of capital being produced, where $i_{t}=I_{t} / K_{t-1}$.

Monetary Policy and Price Setting For simplicity, I assume a flexible price environment, with a monetary policy rule such that the government sets rates as needed to exactly hit its infla- 
tion target of $\bar{\pi}$ in all periods.

Government The government applies a proportional tax at rate $\tau$ to labor income and firm profits (earnings before taxes). The government then rebates the collected funds lump-sum to the household using a transfer $T_{t}$, maintaining a balanced budget at all times.

Representative Firm's Problem. The representative firm solves

$$
V_{t}^{F}=\max _{D_{t}, N_{t}, B_{t}, i_{t}} \Psi\left(D_{t}\right)+\beta E_{t}\left[\Lambda_{t+1}^{H} V_{t+1}^{F}\right]
$$

where $\Lambda_{t+1}^{H}$ is the household's stochastic discount factor, subject to the budget constraint

$$
D_{t} \leq \underbrace{(1-\tau)\left[F\left(K_{t-1}, N_{t}\right)-w_{t} N_{t}-r_{t} \pi_{t}^{-1} B_{t-1}\right]}_{\text {earnings }}+\underbrace{\tau \delta K_{t-1}}_{\text {depreciation }}-\underbrace{i_{t} K_{t-1}}_{\text {investment }}+\underbrace{\left(B_{t}-\pi_{t}^{-1} B_{t-1}\right)}_{\text {net new debt }}
$$

the borrowing constraint (3), and the laws of motion (2) and

$$
K_{t}=\left(\Phi\left(i_{t}\right)+(1-\delta)\right) K_{t-1}
$$

The firm's optimality conditions with respect to labor is the standard

$$
F_{N, t}=w_{t}
$$

In principle, the firm's labor decision could be distorted through incentives to influence the debt limit. However, in this paper, the debt limits considered either do not depend on labor (Leverage covenants) or depend on labor only through EBITDA (Debt/Earnings and Interest Coverage covenants). Since EBITDA is already maximized by (4), any additional term due to the constraint is zero at equilibrium through the envelope theorem.

Next, the firm's optimality condition for debt is

$$
1-\mu_{t}=E_{t}\left\{\Lambda_{t+1}^{F} \pi_{t+1}^{-1}\left[1+(1-\tau) r_{t}\right]\right\}
$$

where $\mu_{t}$ is the multiplier on the debt limit, and $\Lambda_{t+1}^{F}$ is the effective stochastic discount factor of the firm taking into account dividend frictions, defined by

$$
\Lambda_{t+1}^{F}=\left(\frac{\Psi^{\prime}\left(D_{t+1}\right)}{\Psi^{\prime}\left(D_{t}\right)}\right) \Lambda_{t+1}^{H} .
$$


Finally, the firm's investment optimal investment rate is determined by

$$
q_{t}=\Omega_{t}+\mathcal{M}_{t} E_{t}\left[\left(1+r_{t}\right) \frac{\partial \bar{B}_{t+1}}{\partial K_{t}}\right]
$$

where $q_{t}=1 / \Psi^{\prime}\left(i_{t}\right)$ is Tobin's $q, \mathcal{M}_{t}$ is the present discounted value of future debt multipliers, defined by

$$
\mathcal{M}_{t}=\left(1-\rho_{B}\right) \sum_{k=0}^{\infty} E_{t}\left[\left(\prod_{j=0}^{k} \Lambda_{t+j}^{F} \pi_{t+j}^{-1}\right) \rho_{B}^{k} \mu_{t+k}\right]
$$

which takes into account that increasing covenant ratios today relaxes debt limits both today and in the future, through the law of motion (2), while $\Omega_{t}$ is the firm's marginal continuation value of capital, defined by

$$
\Omega_{t}=E_{t}\left\{\Lambda_{t+1}^{F}\left[(1-\tau) F_{K, t+1}+\tau \delta+\left(\Phi\left(i_{t}\right)+(1-\delta)\right) \Omega_{t+1}\right]\right\}
$$

In the case where firms were never borrowing constrained, we would have $\Omega_{t}=q_{t}$, equating the marginal cost of producing capital today with the marginal benefit of future dividends. However, when firms are borrowing constrained, we have $q_{t}>\Omega_{t}$, implying that firms continue investing beyond this level, in order to relax their borrowing limits. I refer to the term $\partial \bar{B}_{t+1} / \partial K_{t}$ as the collateralizability of investment, meaning that investment is more collateralizable when an extra unit of install capital can be financed by more new borrowing due to the relaxed constraint.

Collateralizability of Covenants. Applying the definition of collateralizability to the covenants described earlier, we obtain

$$
\begin{aligned}
\frac{\partial \bar{B}_{t}^{D E}}{\partial K_{t-1}} & =\theta^{D E} F_{K, t} \\
\frac{\partial \bar{B}_{t}^{I C}}{\partial K_{t-1}} & =\frac{\theta^{I C} F_{K, t}}{r_{t}+\omega} \\
\frac{\partial \bar{B}_{t}^{L E V}}{\partial K_{t-1}} & =\theta^{L E V} .
\end{aligned}
$$

These expressions show that collateralizability depends both on the covenant being imposed and potentially on the state of the economy. While Leverage covenants are always equally collateralizable, both Debt/Earnings and Interest Coverage covenants become more collateralizable when the marginal product of capital is high, such as after a positive productivity shock. Most important, however, is that Interest Coverage covenants, but not Debt/Earnings or Leverage covenants, are influenced by interest rates, increasing when interest rates are low. Due to the structure of the constraint, this effect can be quite strong - for example, a fall in the with-spread rate $r_{t}+\omega$ from 
$10 \%$ to $9 \%$ would increase collateralizability by $10 \%$.

Representative Household's Problem. The representative household is relatively standard and will be described briefly. The household chooses $B_{t}$ and $N_{t}$ to maximize (1) subject to the budget constraint

$$
C_{t} \leq \underbrace{\Psi\left(D_{t}\right)}_{\text {dividend }}+\underbrace{(1-\tau) w_{t} N_{t}}_{\text {labor income }}-\underbrace{\left(B_{t}-\left(1+r_{t-1}\right) \pi_{t}^{-1} B_{t-1}\right)}_{\text {net debt issuance }}+\underbrace{T_{t}}_{\text {transfer }} .
$$

The household's resulting optimality conditions are

$$
\begin{array}{ll}
\left(N_{t}\right): & w_{t} u^{\prime}\left(C_{t}\right)=v^{\prime}\left(N_{t}\right) \\
\left(B_{t}\right): & 1=\left(1+r_{t}\right) E_{t}\left[\Lambda_{t+1}^{H} \pi_{t+1}^{-1}\right] .
\end{array}
$$

Equilibrium. A competitive equilibrium consists of allocations $\left(C_{t}, B_{t}, D_{t}, N_{t}, K_{t}, i_{t}\right)$ and prices $\left(r_{t}, \pi_{t}, w_{t}\right)$ such that households and firms optimize, the monetary policy rule is satisfied, the bond and labor markets clear, and the resource constraint

$$
F\left(K_{t-1}, N_{t}\right)=C_{t}+i_{t} K_{t-1}
$$

is satisfied.

Parameterization. This section describes the parametric functions used. For the utility functions I set

$$
u(C)=C, \quad v(N)=\eta \frac{N^{1+\varphi}}{1+\varphi} .
$$

This risk-neutral parameterization keeps interest rates pinned down by the discount factor, and abstracts from smoothing motives other than for dividend smoothing. For the dividend issuance cost I set

$$
\Psi\left(D_{t}\right)=a_{D, 0}+a_{D, 1} \frac{D_{t}^{1-\zeta_{D}}}{1-\zeta_{D}}
$$

where $a_{D, 0}$ and $a_{D, 1}$ are chosen to satisfy

$$
\Psi\left(D_{s s}\right)=D_{s s} \quad \quad \Psi^{\prime}\left(D_{s s}\right)=1
$$


This functional form implies that the firm's SDF is given by

$$
\Lambda_{t+1}^{F}=\left(\frac{D_{t+1}}{D_{t}}\right)^{-\zeta_{D}} \Lambda_{t+1}^{H}
$$

implying a familiar smoothing motive for dividends. For simplicity, in the baseline calibration I ignore capital adjustment costs, so that $\Phi\left(i_{t}\right)=i_{t}$, implying that Tobin's $q$ is equal to unity.

Calibration. The values of calibrated parameters can be found in Table 2.

Table 2: Parameter Values: Baseline Calibration

\begin{tabular}{|c|c|c|c|c|}
\hline Parameter & Name & Value & Internal & Target/Source \\
\hline \multicolumn{5}{|c|}{ Demographics, Preferences, and Government } \\
\hline Discount factor mean & $\bar{\beta}$ & 0.983 & $\mathrm{~N}$ & Jermann and Quadrini (2012) \\
\hline Discount factor persistence & $\rho_{\beta}$ & 0.992 & $\mathrm{~N}$ & Autocorrelation of 3-Mo T-Bill \\
\hline Labor disutility scale & $\eta$ & 1.016 & Y & $N_{S S}=1$ \\
\hline Inv. Frisch elasticity & $\varphi$ & 1.000 & $\mathrm{~N}$ & Standard \\
\hline Tax rate & $\tau$ & 0.350 & $\mathrm{~N}$ & Standard \\
\hline \multicolumn{5}{|c|}{ Productive Technology } \\
\hline Capital share & $\alpha$ & 0.360 & $\mathrm{~N}$ & Standard \\
\hline Depreciation & $\delta$ & 0.025 & $\mathrm{~N}$ & Standard \\
\hline Dividend cost elasticity & $\zeta_{D}$ & 1.000 & $\mathrm{~N}$ & Moderate smoothing \\
\hline \multicolumn{5}{|c|}{ Debt Covenants } \\
\hline Borrowing limit smoothing & $\rho_{B}$ & 0.250 & $\mathrm{~N}$ & Annualized ratios \\
\hline Max Debt/Earnings ratio & $\theta^{D E}$ & 8.040 & $\mathrm{Y}$ & Debt $/$ GDP $=3.36$ in DE Economy \\
\hline Max Interest Coverage ratio & $\theta^{I C}$ & 0.197 & $\mathrm{Y}$ & Debt/GDP $=3.36$ in IC Economy \\
\hline Max Leverage ratio & $\theta^{L E V}$ & 0.962 & Y & Debt $/$ GDP $=3.36$ in Lev. Economy \\
\hline IC vs. DE st. dev. & $\sigma_{e}$ & 0.301 & $\mathrm{~N}$ & DealScan \\
\hline
\end{tabular}

\section{Model Results}

This section presents the main results from the theoretical model. The main experiment is an impulse response to a fall in the interest rate, obtained through an increase in the discount factor $\beta_{t}$. All results are obtained by linearizing around the steady state of the model.

Interest Transmission by Covenant. The first set of results consider how the different covenants influence transmission. For this exercise, I compare a Debt/Earnings Economy, an Interest Coverage Economy, and a Leverage Economy, where each imposes only that covenant as the limit 
on firm borrowing. I calibrate the debt limits in all three economies to have the same Debt/GDP ratio, matching the 3.36 target (annual) of Jermann and Quadrini (2012). Figure 3 contrasts the response to a monetary policy shock across the three economies. The responses show that, although interest rates fall in all three economies, a monetary policy shock increases debt by much more in the Interest Coverage Economy (11.9\% after 8 quarters) than in either of the alternative economies (increases of $0.57 \%$ and $1.47 \%$ in the DE and Leverage economies, respectively).
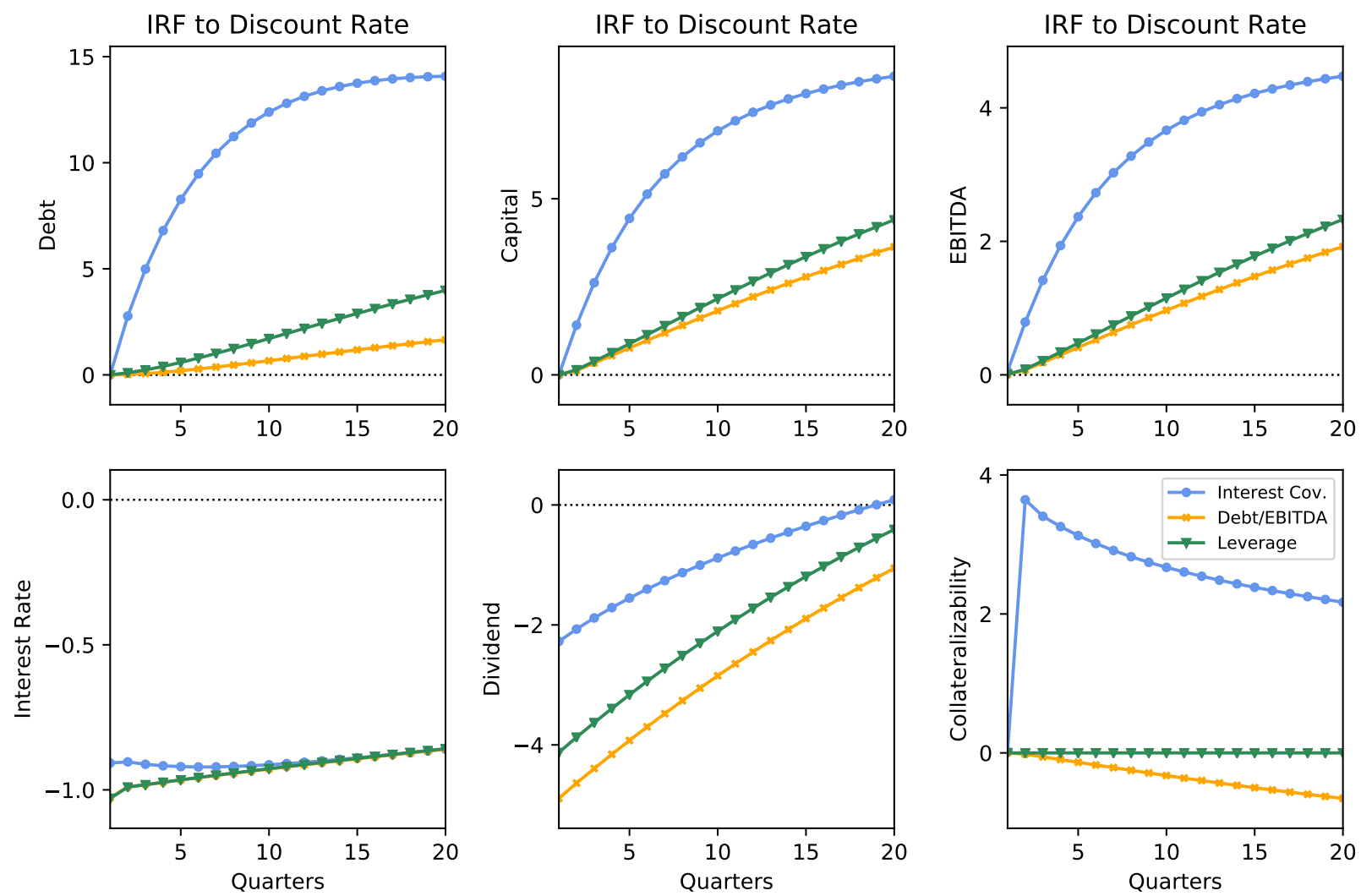

Figure 3: Interest Rate Transmission by Covenant

While the increased sensitivity of debt to the fall in rates is simply due to the structure of the covenants, the response of debt in the IC economy is amplified by the increase in EBITDA driven by increased investment. While firms in all three economies invest more in response to a fall in discount rates, firms in the IC economy invest much more, due to the combination of their access to debt finance, a sharp increase in collateralizability, and dividend issuance costs that discourage the firms from paying out the new debt to investors. As a result, IC-constrained firms increase their capital by $6.6 \%$ after 8 quarters, far outstripping the DE economy $(1.6 \%)$ or the Leverage economy $(1.5 \%)$. This increase investment in turn finances additional borrowing, since elevated EBITDA also relaxes IC limits. This feedback channel from debt to EBITDA in the IC economy allows EBITDA to rise by $3.5 \%$ after 8 quarters, further relaxing debt limits by an identical amount. 
These results show that a calibrated model with a tax shield motive for debt and a modest degree of dividend smoothing can produce greatly amplified transmission from interest rates into debt and investment when firms are limited by IC covenants.

Next, we can turn to the second main insight of the paper: that when firms have multiple covenants, transmission is state dependent, and is stronger when interest rates are high, meaning that interest coverage covenants are tight. To do this, Figure 4 compare three versions of an economy in which all firms have both IC and DE covenant, with the dispersion between the relative tightness of the two calibrated to match the dispersion observed in the DealScan data. These economies only differ in their steady state interest rates $(\bar{\beta})$. The Low Rates economy has a steady state discount rate that is $100 \mathrm{bp}$ lower, while the High Rates economy has a steady state discount rate that is $100 \mathrm{bp}$ higher.
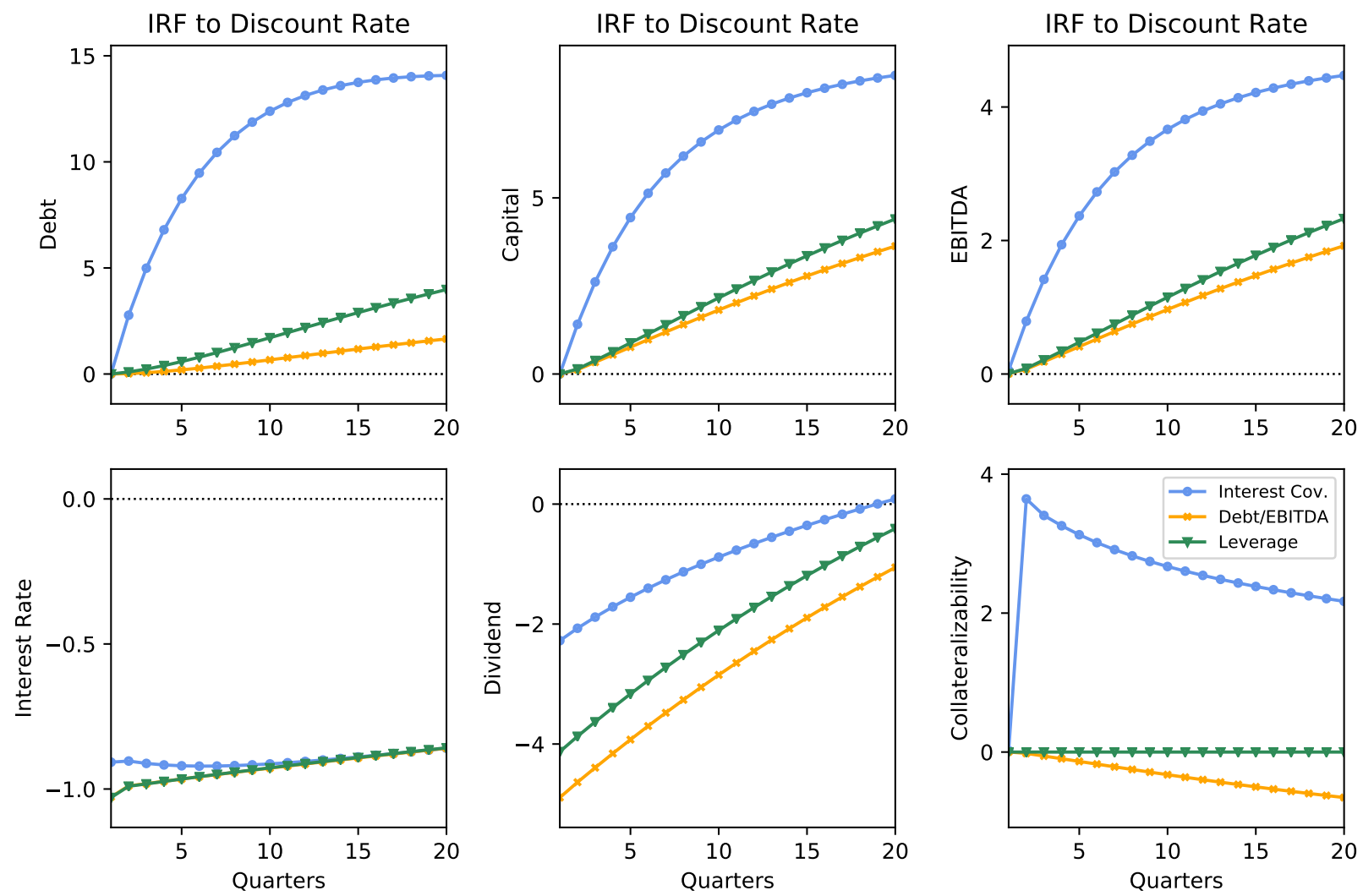

Figure 4: Transmission with Debt/Earnings and Interest Coverage Covenants

First, consider the Hybrid DE/IC economy. Using the same debt constraint $(\theta)$ parameters as in the previous analysis implies an environment in which the two covenants are approximately balanced, leading to results between the IC and DE economies in Figure 3, with debt and capital 


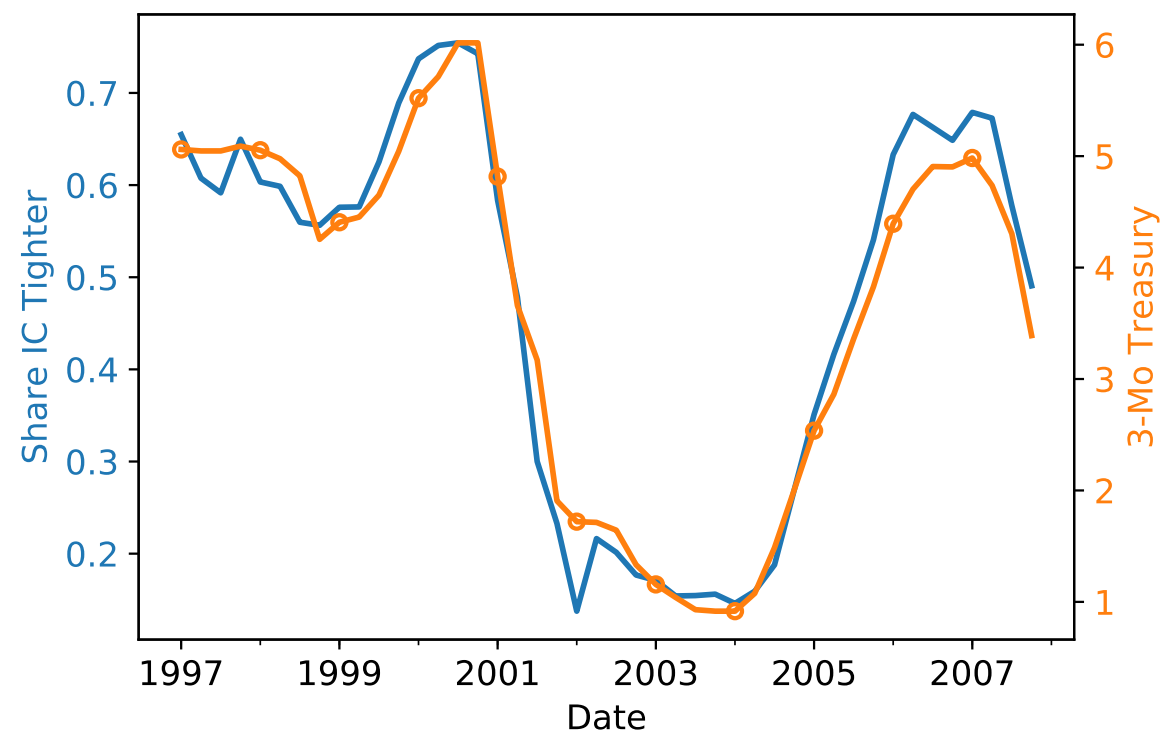

Figure 5: Implied Share with Tighter Interest Coverage Covenant

Note: Source: DealScan and the Federal Reserve Board of Governors.

increasing by $4.7 \%$ and $7.7 \%$ after 8 quarters. However, the results in the alternative interest rate regimes are strikingly different. Under high interest rates, high interest payments tighten Interest Coverage limits, implying that more firms find Interest Coverage to be their binding limit. As a result, the responses are nearly as large as in the IC-only economy, since more firms are affected by the sharp loosening of IC limits. In contrast, the low-rate economy finds only a minority of firms to be constrained by their IC covenants, leading to a much smaller quantitative response.

How relevant is this state dependence likely to be in reality? Figure 5 shows the implied evolution of the share of firms with both IC and DE covenants for which the IC covenant is tighter. Due to the structure of the two covenants, which of the two is tighter depends only on the ratios $\theta_{i, t}^{I C}$ and $\theta_{i, t}^{D E}$, obtained from DealScan, and the firm-specific interest rate $r_{i, t}$. To proxy for this rate, I augment the 3-Month T-Bill rate with a 600bp spread. The figure shows that as the interest rate has varied since the mid-1990s, the implied share of firms for whom Interest Coverage is their tightest covenant has undergone wide variation, from a high of roughly $70 \%$ in 2000 and in the run-up to the financial crisis, to lows of under $10 \%$ as the economy hovered near the zero lower bound. These results indicate that the sensitivity of firm credit and investment to monetary policy may have been much weaker both at the start of the housing boom (2002-2004) and especially during the post-crisis recession, when stimulus was desparately needed. 


\section{Empirical Results}

In this section, I investigate the main implications of the model - amplified interest rate transmission through Interest Coverage covenants and state-dependent transmission when firms have both Interest Coverage as well as Debt/Earnings or Leverage covenants — hold in the data. ${ }^{7}$

Data Construction. To construct the data set, I merge syndicated loan data from DealScan with firm data from Compustat, following the linking procedure in Chava and Roberts (2008). The DealScan data contains covenant information for syndicated loans, which is used to classify the firms into different covenant categories, while Compustat provides the other firm-level variables used in the regressions. I restrict the sample to the period 1994Q1 - 2007Q4. This starting date is roughly the date at which the share of firms with DealScan covenants stabilizes, providing even coverage throughout the sample. The ending date is chosen to avoid the financial crisis, since Chodorow-Reich and Falato (2017) document that the enforcement of covenant violations changed dramatically during this period, potentially altering the responses of interest. This end date also avoids the zero lower bound period, when interest rate transmission is harder to measure.

Empirical Strategy The overall empirical approach is to compare the response of measures of firm capital and debt to a change in interest rates. A classic concern in the literature studying interest rate transmission is that a change in interest rates is typically not exogenous, but occurs in response to some other shock, which may have confounding effects on the dependent variables. To address this, I include time effects in all my regressions, to absorb the level effect of macroeconomic conditions. An alternative approach would be to use identified monetary policy shocks, which are ideally close to exogenous, in place of the change in the interest rate. Results using this approach (found in Appendix figure 11) are similar, with the main difference being that monetary policy shocks are less persistent than typical interest rate movements.

Transmission by Covenant To show how transmission varies by covenant, I run the regression

$$
y_{i, t+h}=\alpha_{i}+\phi_{t}+\sum_{\mathrm{cov}} \mathbb{I}_{\mathrm{cov}, t} \cdot\left(\beta_{0, \mathrm{cov}}+\beta_{1, \mathrm{cov}} \Delta r_{t}\right)+\gamma^{\prime} X_{t-1}+\delta^{\prime}\left(X_{t-1} \cdot \Delta r_{t}\right)+\varepsilon_{i, t}
$$

where $\alpha_{i}$ is a firm effect, $\phi_{t}$ is a time effect, $\mathbb{I}_{\mathrm{cov}, t}$ is an indicator that the firm has a covenant, where "cov" is one of Interest Coverage, Debt/Earnings, or Leverage, $\Delta r_{t}$ is the change in the 3Month T-Bill rate, and $X_{t-1}$ is a vector of firm-level controls: cash, EBITDA, assets, long-term debt, short-term debt, and CapEx. Both the dependent variable $y_{i, t+h}$ and the controls $X_{t-1}$ are scaled (divided) by lagged Property, Plant, and Equipment $\left(P P E_{t-1}\right)$, allowing comparability across firms

\footnotetext{
${ }^{7}$ While not shown in Figure 1b, results pairing IC and Leverage covenants instead of IC and DE covenants would induce very similar state dependence.
} 
of different scales. Including time effects controls for macroeconomic conditions that may have influenced $\Delta r_{t}$, while including the interaction between controls and $\Delta r_{t}$ allows for interest rate changes to have differential effects on firms with different underlying fundamentals.

The results of regression (6) for firm capital, measured as Property, Plant, and Equipment (PPE), and total debt are displayed in Figure 7. For consistency with the theoretical results, responses are plotted with respect to an interest rate decline $\left(-\Delta r_{t}\right)$. These figures plot $\beta_{1, \text { cov }}$ for each horizon $h$. Note that this coefficient represents the differential effect of a 100bp decline in rates for Interest Coverage firms relative to firms without any covenants, not the absolute effect of the change, due to the time effects.

The top row of Figure 7 demonstrates that firms with Interest Coverage covenants increase their investment and debt levels relative to firms without covenants. The results, while not very precisely estimated, are statistically significant at a number of horizons, and place most of the probability mass in economically significant regions. For PPE, we observe an increase of between $2 \%$ and $6 \%$ after 8 quarters (point estimate: $4.1 \%$ ). For debt, we observe a corresponding increase of between $30 \%$ and $55 \%$ of $P P E_{t-1}$ (point estimate: $42.6 \%$ ). Note that the change in debt is also measured proportional to $P P E_{t-1}$, not to starting debt, which implies that the proportional increase in debt is smaller than these reported figures, as the typical firm with an IC covenant has debt that exceeds PPE. Nonetheless, the data point to a substnatial increase in both variables.

Although regression (6) interacts the change in interest rate with a number of key controls, 1 showed that firms with no covenants are quite different in scale from firms with IC covenants, leading to potential concern that this differential response is confounded by a difference across firms unrelated to their covenant structure. To address this, the second row of Figure 7 compares the coefficients on $\beta_{1, \text { cov }}$ for IC covenants against the coefficients for DE covenants. While firms with DE covenants are quite similar on measure of scale and other firm statistics to firms with IC covenants, possessing a DE covenant is not associated with a high investment or debt response to changes in interest rates. The point estimates imply that firms with DE covenants respond slightly less to changes in rates than firms without covenants, although the difference is not statistically significant at any horizon. This comparison of more similar firms reinforces the idea that it is the difference in the covenant structure specifically that is associated with the strengthened investment and debt response.

For a more formal analysis, we can compute the difference in $\beta_{1, I C}-\beta_{1, D E}$, measuring the difference in response of firms with IC covenants relative to firms with DE covenants. The results, displayed in the bottom row of Figure 7, show that the difference between these otherwise similar firms are economically and mostly statistically significant. The point estimate of the difference in PPE after 8 quarters is $8.4 \%$, slightly larger than the 5.0\% difference in 8Q capital growth implied by the calibrated model, although the bands are consistent with a wide range of positive differences, including that of the model. Overall, this empirical exercise supports the hypothesis that 

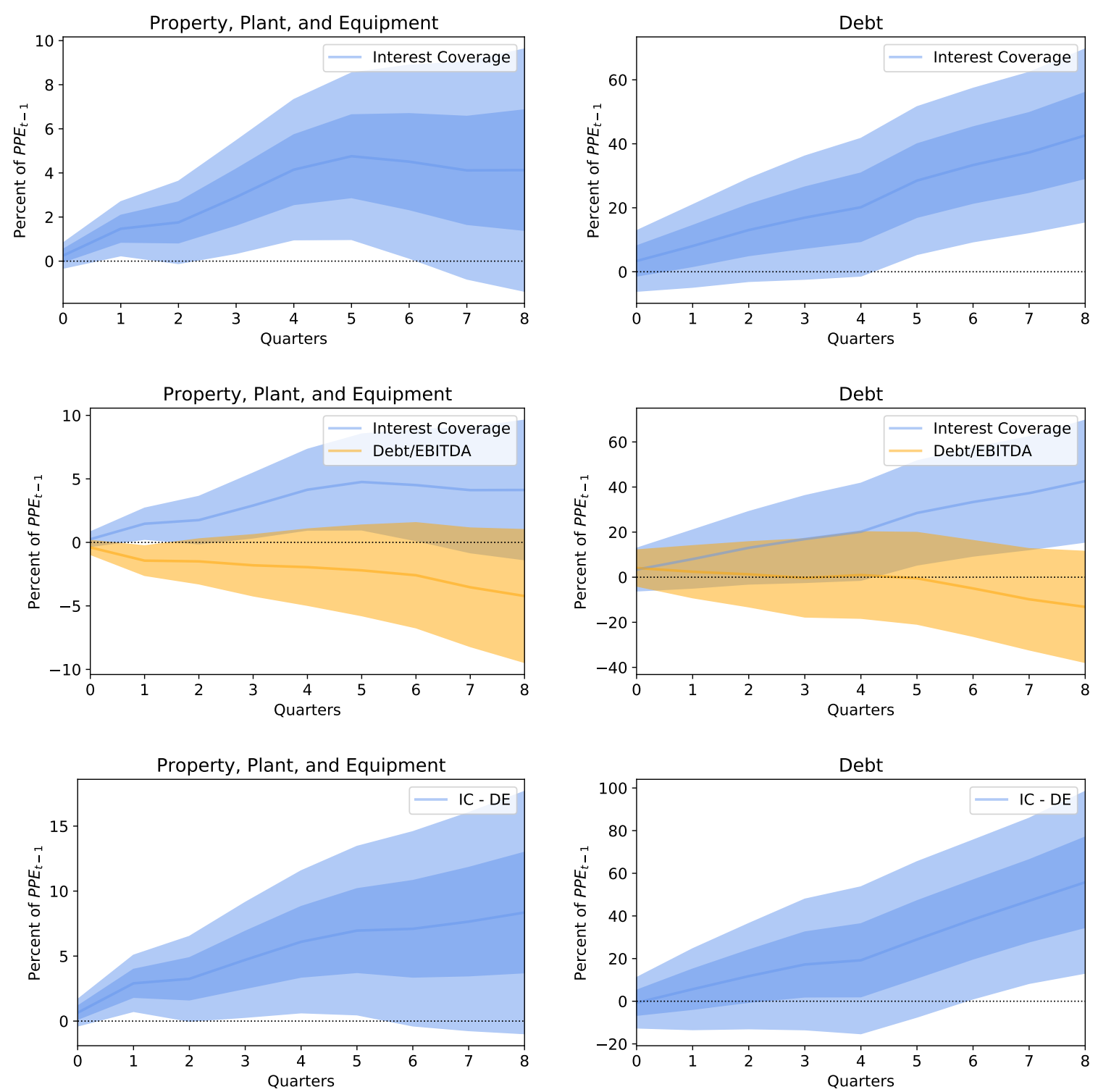

Figure 6: Response to Interest Rate (Decrease) by Covenant

Note: The lines labeled "Interest Coverage," "Debt/EBITDA," and "Leverage" plot the coefficients on $\beta_{1, \text { cov }}$ in equation (6), along with $67 \%$ (dark) and 95\% (light) confidence bands. The lines labeled "IC - DE" plot the differences between the coefficients, along with confidence bands. Standard errors are clustered at the firm level.

IC covenants amplify interest rate transmission.

Next, we can test the second key prediction of the theory: state dependent tranmission, with greater amplification when interest rates are high - and more firms are IC-constrained - relative to when rates are low. To do this, I augment regresison (6) to allow for different coeffients 

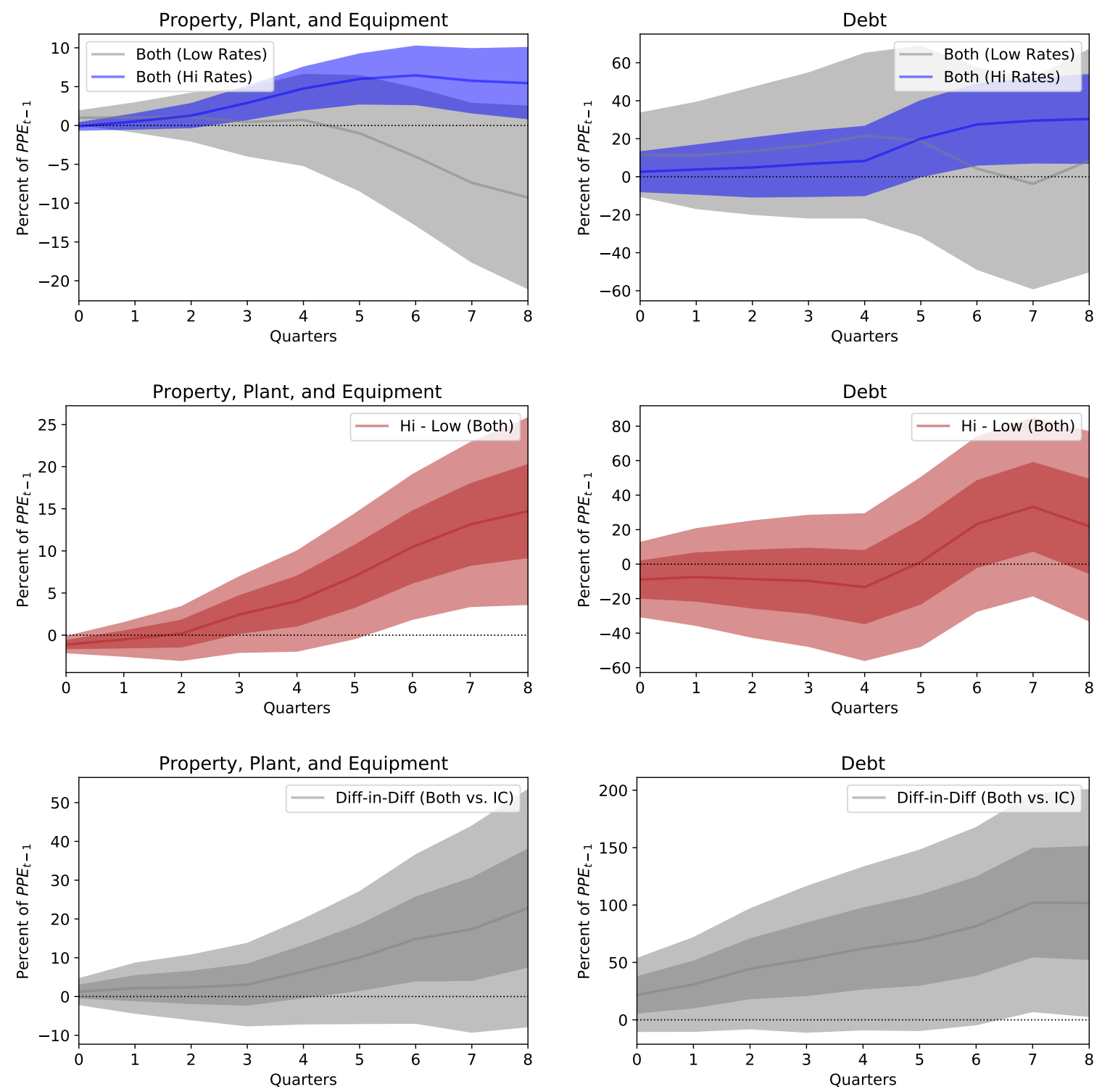

Figure 7: Response to Interest Rate (Decrease) by Current Rate

Note: The plots display coefficients on $\beta_{1 \text {,cov }}$ in equation (6), along with $67 \%$ (dark) and $95 \%$ (light) confidence bands. The labels "Low Rates" and "High Rates" refer to lagged 3-Mo T-Bill rates being below and above $3.5 \%$, respectively. The lines "Hi - Low" plot the difference between coefficients in the high and low rate regimes. The "Diff-in-Diff' lines plot the difference in these differences between firms with both an IC covenant and another covenant vs. firms with only an IC covenant. Standard errors are clustered at the firm level.

depending on the interest rate regime:

$$
y_{i, t+h}=\alpha_{i}+\phi_{t}+\sum_{s \in\{h i, l o w\}} \mathbb{I}_{s, t}\left\{\sum_{\operatorname{cov}} \mathbb{I}_{\mathrm{cov}, t} \cdot\left(\beta_{0, \mathrm{cov}}^{s}+\beta_{1, \mathrm{cov}}^{s} \Delta r_{t}\right)+\gamma_{s}^{\prime} X_{t-1}+\delta_{s}^{\prime}\left(X_{t-1} \cdot \Delta r_{t}\right)\right\}+\varepsilon_{i, t}
$$


where $s=$ hi means that the lagged 3-Month T-Bill rate $r_{t-1}$ is above 3.5\%, while $s=$ low means that $r_{t-1}$ is below $3.5 \%$. This cutoff is chosen to be approximately the point at which most firms in the sample with both an IC and DE covenant would find the IC limit to be tighter than the DE limit, and is close to the sample median.

Figure 6 displays the results of regression (7), specifically the coefficients on $\beta_{1, \text { cov }}^{s}$. To begin, focus on the left column, relating to investment. The top panel displays the coefficients for firms with both an IC covenant, and another covenant (either DE or Leverage). This plot shows that the earlier result from Figure 7 that firms with IC covenants invest more following a fall in interest rates only holds in the high interest rate regime. Point estimates in the low interest rate regime, while imprecisely estimated, are close to zero or negative. To test this difference more formally, the second row plots the difference between $\beta_{1, \text { both }}^{\text {hi }}-\beta_{1, \text { both }}^{\text {low }}$ along with its standard error, indicating that the difference is economically large and statistically significant at longer horizons.

To test the hypothesis that it is specifically the combination of two covenants that induces the state dependence, the third row displays the difference in difference of the coefficients

$$
\left(\beta_{1, \text { both }}^{\text {hi }}-\beta_{1, \text { both }}^{\text {low }}\right)-\left(\beta_{1, I C}^{\text {hi }}-\beta_{1, I C}^{\text {low }}\right)
$$

While very imprecisely estimated, this figure is consistent with an increase in the state dependence of transmission for firms with both an IC covenant and a second covenant that does not depend directly on interest rates.

The results on debt, in the right column, are very imprecisely estimated. The most interesting finding is the difference-in-difference estimation, which points to stronger state dependence for firms with both covenants. Improved covenant data would likely be needed to evaluate the debt response with more confidence.

\section{Conclusion}

In this paper, I argued that Interest Coverage covanents can greatly amplify interest rate transmission. The data indicate that these covenants are extremely common, and are imposed a stable ratios over time, implying substantial variation in debt limits as interest rates fluctuate. Using a simple model where firm borrowing is limited by realistic covenants and where firms face frictions on dividend issuance, I showed that the presence of IC covenants can dramatically increase the response of firm investment and borrowing to interest rate changes. Moreover, when, as is typical, firms face both IC and non-IC covenants, state dependent transmission emerges, such that the response of firm debt and capital is stronger when existing rates are high (and IC covenants are more likely to bind) than when they are low. Both of these findings are supported by firm-level regressions. 
Looking ahead, there are a number of avenues open for further study. First, while I treat debt covenants as imposing hard limits that cannot be exceeded, in reality firms often violate and renegotiate their covenants. Modeling a penalty for violation in place of a hard limit, and investigating the empirical properties of violation in the data, could yield additional insights. In particular, firms may have a much stronger precautionary motive with respect to IC covenants due to their extreme volatility. With DE covenants, firms only need to worry about accidentally violating because earnings fell. With IC covenants, firms must contend both with stochastic earnings, as well as changes in the interest rate, which could cause firms to unintentionally violate their covenants even when their earnings remain healthy. Overall, the role of debt covenants in macroeconomic dynamics may prove to be fertile ground for a number of future studies. 


\section{References}

Bernanke, B. S. And M. Gertler (1995): "Inside the Black Box: The Credit Channel of Monetary Policy Transmission," Journal of Economic perspectives, 9, 27-48.

Bernanke, B. S., M. Gertler, AND S. Gilchrist (1999): “The Financial Accelerator in a Quantitative Business Cycle Framework," Handbook of macroeconomics, 1, 1341-1393.

Chava, S. And M. R. Roberts (2008): “How Does Financing Impact Investment? The Role of Debt Covenants," The Journal of Finance, 63, 2085-2121.

Chodorow-Reich, G. AND A. Falato (2017): “The Loan Covenant Channel: How Bank Health Transmits to the Real Economy," Tech. rep., National Bureau of Economic Research.

DRESCHEL, T. (2018): "Earnings-Based Borrowing Constraints and Macroeconomic Fluctuations," Working Paper, London School of Economics.

JERMANN, U. AND V. QUADRINI (2012): "Macroeconomic Effects of Financial Shocks," American Economic Review, 102, 238-71.

LiAn, C. AND Y. MA (2017): “Anatomy of Corporate Borrowing Constraints," Working Paper, Massachusetts Institute of Technology.

Roberts, M. R. AND A. SUfi (2009): “Control Rights and Capital Structure: An Empirical Investigation," The Journal of Finance, 64, 1657-1695.

TOWNSEND, R. M. (1979): “Optimal Contracts and Competitive Markets With Costly State Verification," Journal of Economic theory, 21, 265-293. 


\section{A Additional Tables and Figures}

Table 3: Firm Medians by Covenant Type (Additional Groupings)

\begin{tabular}{|c|c|c|c|c|c|c|}
\hline & None & IC & Non-IC & IC Only & DE Only & Lev Only \\
\hline & \multicolumn{6}{|c|}{ Levels (Million USD) } \\
\hline Sales & 8.56 & 118.36 & 53.65 & 104.88 & 115.16 & 33.53 \\
\hline EBITDA & 0.39 & 13.99 & 4.84 & 8.10 & 9.71 & 2.66 \\
\hline Assets & 57.33 & 449.83 & 190.61 & 308.71 & 361.14 & 141.53 \\
\hline PPE & 5.24 & 96.72 & 33.42 & 78.46 & 83.81 & 20.72 \\
\hline Debt & 2.88 & 138.26 & 25.77 & 82.36 & 98.83 & 12.21 \\
\hline ST Debt & 0.46 & 5.48 & 3.04 & 5.90 & 6.67 & 2.33 \\
\hline LT Debt & 0.77 & 115.31 & 12.82 & 57.77 & 77.58 & 5.94 \\
\hline \multirow[t]{2}{*}{ Cash } & 7.95 & 14.80 & 22.11 & 12.12 & 24.47 & 23.18 \\
\hline & \multicolumn{6}{|c|}{ Scaled Levels (Multiple of Quarter Median) } \\
\hline Sales & 0.43 & 5.64 & 2.58 & 4.99 & 5.03 & 1.75 \\
\hline EBITDA & 0.22 & 7.89 & 2.71 & 4.46 & 5.15 & 1.47 \\
\hline Assets & 0.48 & 3.68 & 1.60 & 2.55 & 2.75 & 1.22 \\
\hline PPE & 0.42 & 7.58 & 2.66 & 6.03 & 6.06 & 1.66 \\
\hline Debt & 0.30 & 14.24 & 2.65 & 8.26 & 10.65 & 1.24 \\
\hline ST Debt & 0.42 & 5.11 & 2.77 & 5.50 & 6.71 & 2.09 \\
\hline LT Debt & 0.19 & 28.07 & 3.26 & 14.13 & 19.57 & 1.39 \\
\hline \multirow[t]{2}{*}{ Cash } & 0.80 & 1.40 & 2.19 & 1.11 & 2.18 & 2.54 \\
\hline & \multicolumn{6}{|c|}{ Ratios } \\
\hline Debt/EBITDA & 0.00 & 8.44 & 3.12 & 7.37 & 5.35 & 2.04 \\
\hline Debt/Assets & 0.12 & 0.32 & 0.18 & 0.30 & 0.24 & 0.16 \\
\hline Market-to-Book & 1.72 & 1.38 & 1.56 & 1.36 & 1.51 & 1.60 \\
\hline$N$ & 184,275 & 69,824 & 13,286 & 5,726 & 3,830 & 7,532 \\
\hline
\end{tabular}

Note: Data source is DealScan and Compustat. The sample is 1994Q1 - 2007Q4. All entries are sample medians. For "Scaled Levels" (top panel), each value is divided by the quarterly median for that variable across all firms, before the median is taken by covenant type. For "Ratios" the values are not scaled before the median is taken. Covenant categories are as follows: "None" firms have no DealScan covenant, "IC" firms have an Interest Coverage covenant, "Non-IC" firms have at least one DealScan covenant but not an IC covenant, "IC Only" firms have only an Interest Coverage covenant and no other covenants, with "DE Only" and "Lev Only" symmetrically defined for Debt/Earnings and Leverage covenants. Variable definitions and Compustat codes are as follows. Sales (code: SALEQ). EBITDA is Earnings Before Interest, Taxes, Depreciation, and Amortization (code: OIBDPQ). Assets (code: ATQ). PPE is Property, Plant, and Equipment (code: PPENTQ). Debt is the sum of ST (short-term) debt (code: DLCQ) and LT (long-term) debt (code: DLTTQ). Cash (code: CHEQ). Market-to-book is the ratio of market equity to book equity. $N$ is the number of variables with a non-missing value for PPE in the sample. 

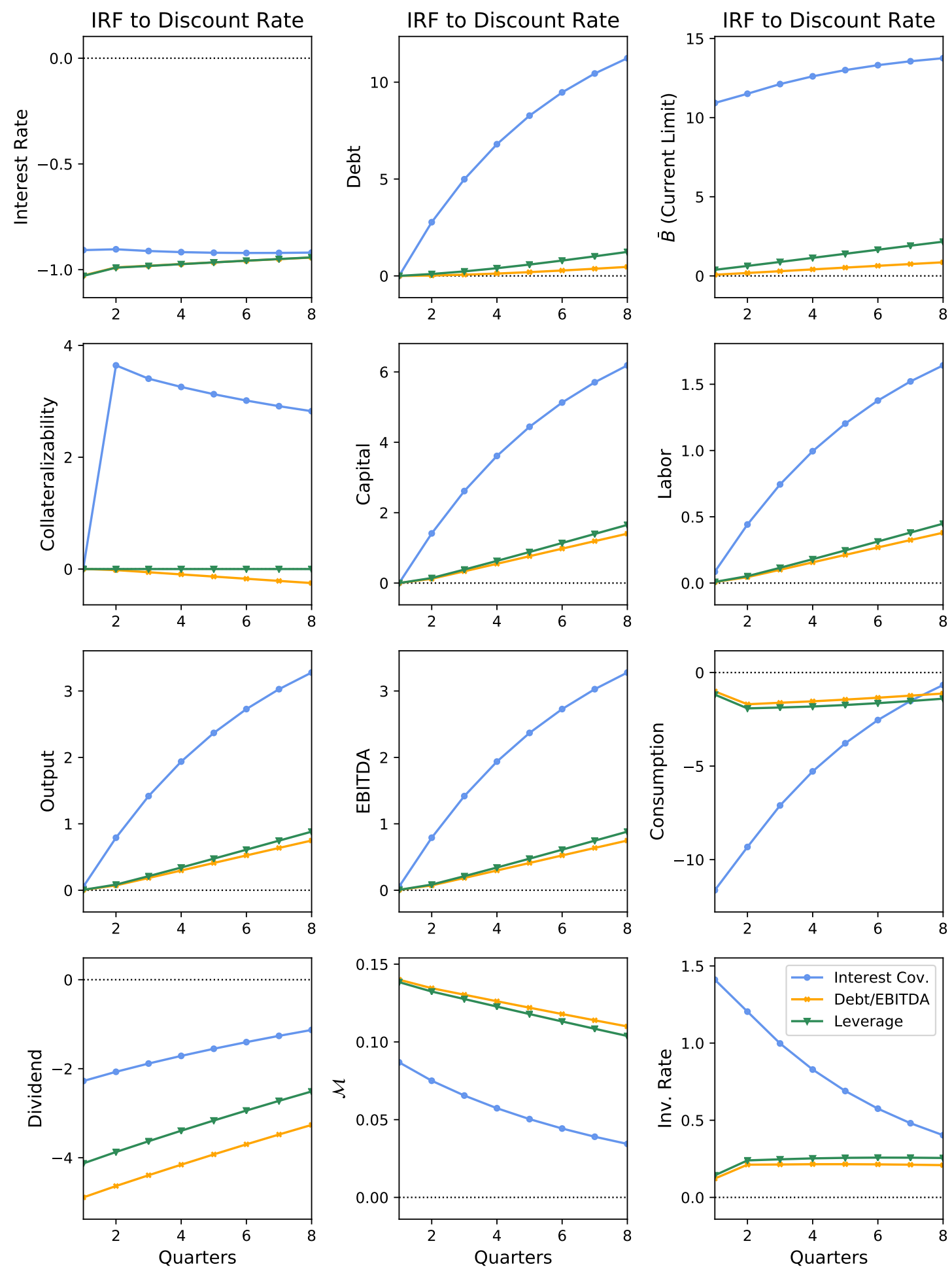

Figure 8: Interest Rate Transmission by Covenant: Additional Variables

Note: All variables are scaled in percent deviations from steady state, with the exceptions of Collateralizability, the discounted multiplier $\mathcal{M}_{t}$, and Inv. Rate $\left(i_{t}\right)$, which are expressed in percentage points. 

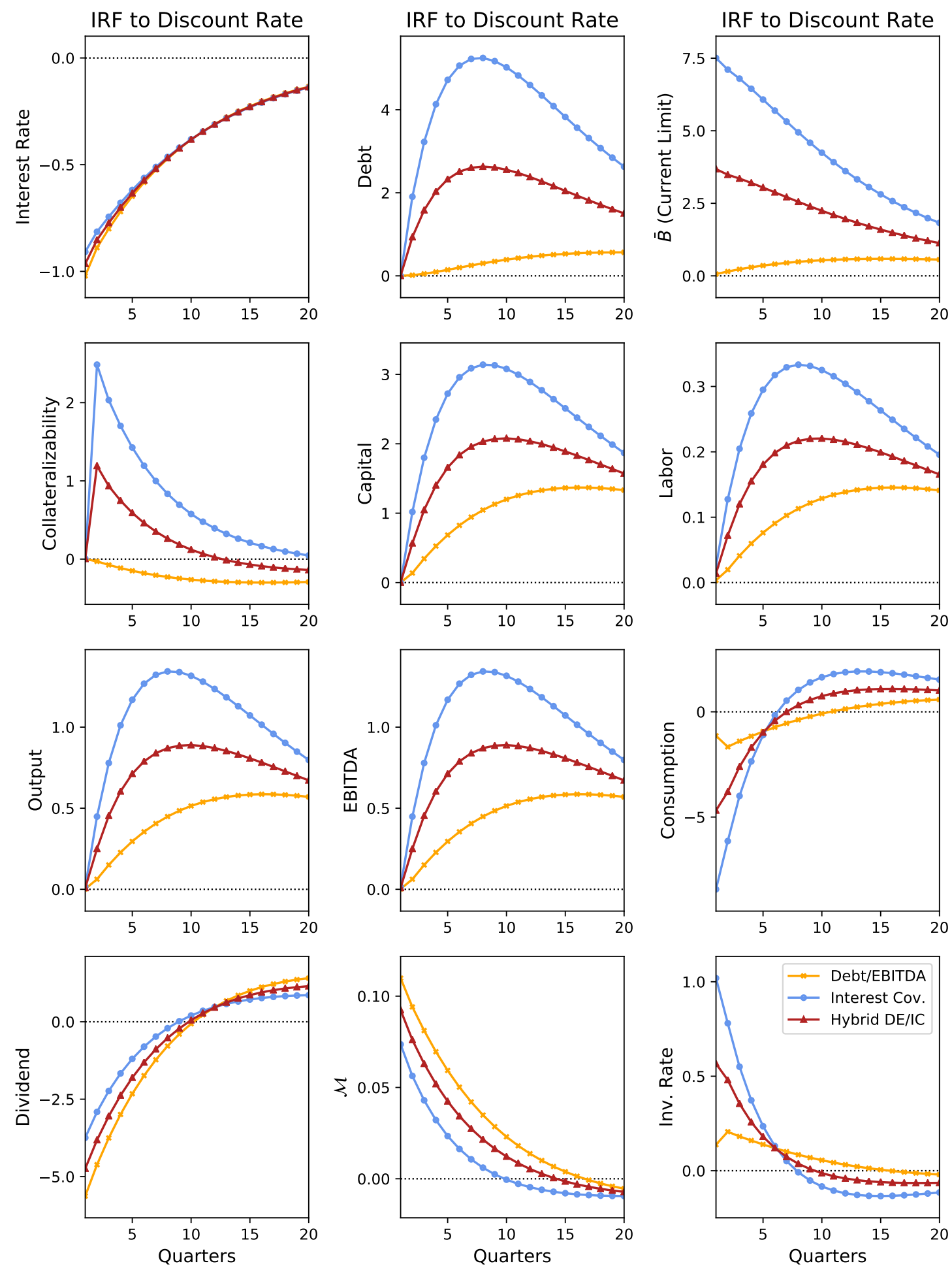

Figure 9: Discount Rate Shock by DE vs. IC vs. Both

Note: All variables are scaled in percent deviations from steady state, with the exceptions of Collateralizability, the discounted multiplier $\mathcal{M}_{t}$, and Inv. Rate $\left(i_{t}\right)$, which are expressed in percentage points. 

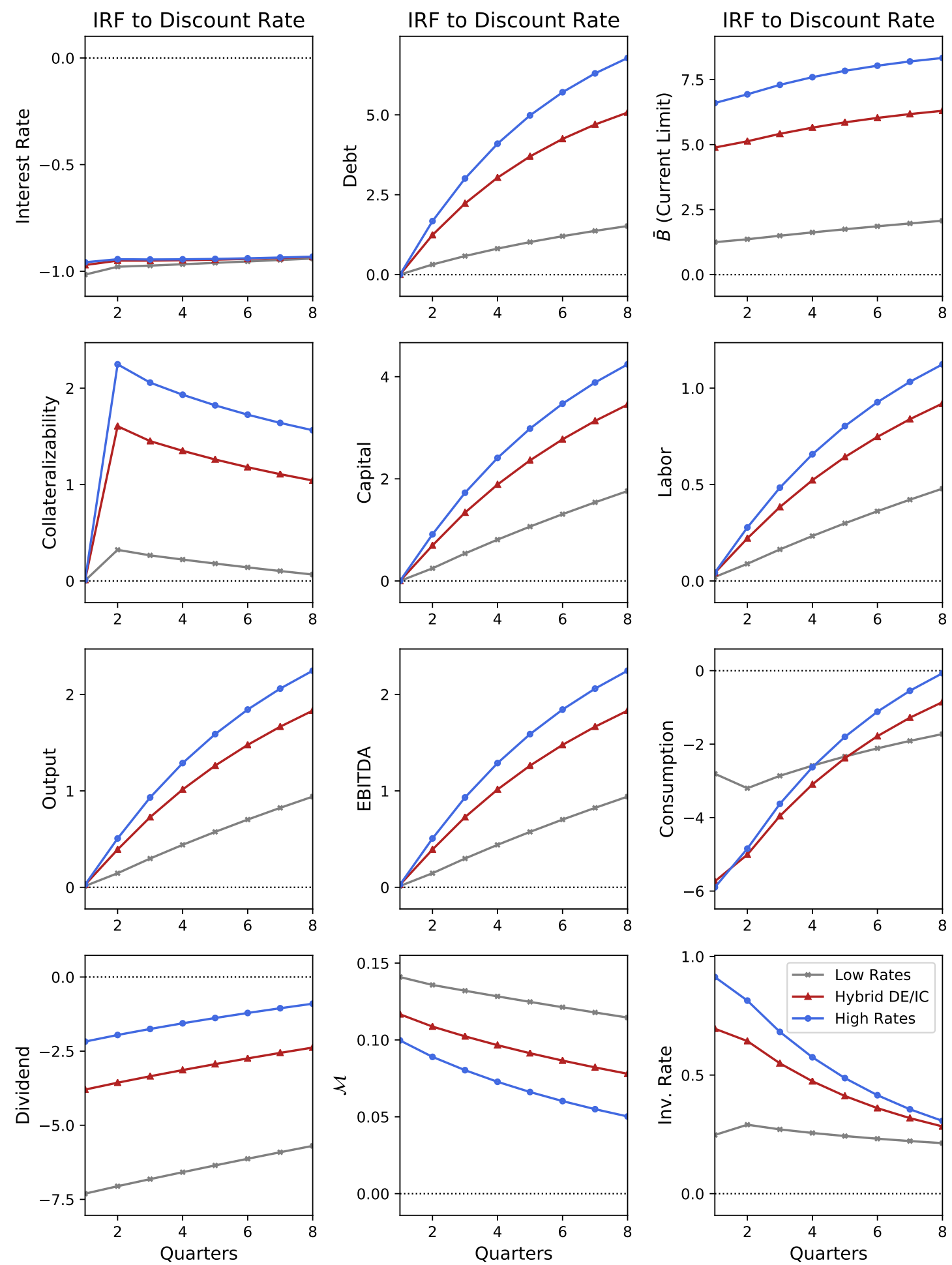

Figure 10: Transmission with DE and IC Covenants: Additional Variables

Note: All variables are scaled in percent deviations from steady state, with the exceptions of Collateralizability, the discounted multiplier $\mathcal{M}_{t}$, and Inv. Rate $\left(i_{t}\right)$, which are expressed in percentage points. 

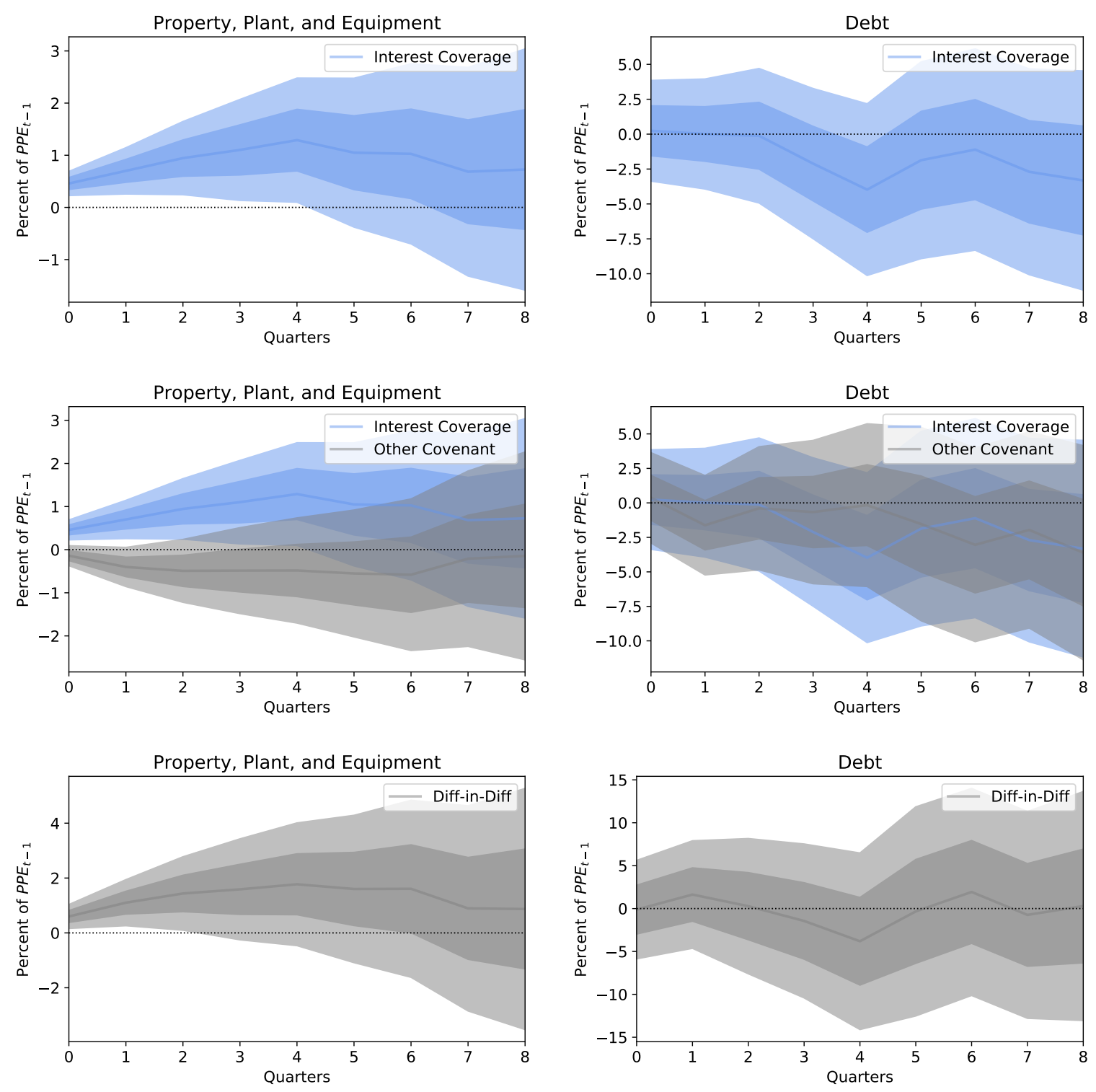

\section{Figure 11: Response to Monetary Policy Shock (Loosening) by Covenant}

Note: These figures plot the coefficients on regression (6), replacing the change in interest rates $\Delta r_{t}$ with identified monetary policy shocks following the procedure of ?. The lines labeled "Interest Coverage," and "Other Covenant" the coefficients on $\beta_{1, \text { cov }}$ in equation (6), where "Other Covenant" pools together $\mathrm{DE}$ and Leverage covenants, along with 67\% (dark) and 95\% (light) confidence bands. The lines labeled "Diff-in-Diff" plot the differences between the coefficients, along with confidence bands. 